\title{
Effect of Maize Hybrid and Foliar Fungicides on Yield Under Low Foliar Disease Severity Conditions
}

\author{
Sally O. Mallowa, Paul D. Esker, Pierce A. Paul, Carl A. Bradley, Venkata R. Chapara, \\ Shawn P. Conley, and Alison E. Robertson
}

First and seventh authors: Department of Plant Pathology and Microbiology, Iowa State University; second author: Escuela de Agronomía, Universidad de Costa Rica; third author: Department of Plant Pathology, Ohio State University; fourth and fifth author: Department of Crop Sciences, University of Illinois at Urbana-Champaign; and sixth author: Department of Agronomy, University of Wisconsin.

Accepted for publication 2 March 2015.

\begin{abstract}
Mallowa, S. O., Esker, P. D., Paul, P. A., Bradley, C. A., Chapara, V. R., Conley, S. P., and Robertson, A. E. 2015. Effect of maize hybrid and foliar fungicides on yield under low foliar disease severity conditions. Phytopathology 105:1080-1089.

Foliar fungicide use in the U.S. Corn Belt increased in the last decade; however, questions persist pertaining to its value and sustainability. Multistate field trials were established from 2010 to 2012 in Illinois, Iowa, Ohio, and Wisconsin to examine how hybrid and foliar fungicide influenced disease intensity and yield. The experimental design was in a split-split plot with main plots consisting of hybrids varying in resistance to gray leaf spot (caused by Cercospora zeae-maydis) and northern corn leaf blight (caused by Setosphaera turcica), subplots corresponding to four application timings of the fungicide pyraclostrobin, and sub-subplots represented by inoculations

with either $C$. zeae-maydis, $S$. turcica, or both at two vegetative growth stages. Fungicide application (VT/R1) significantly reduced total disease severity relative to the control in five of eight site-years $(P<0.05)$. Disease was reduced by approximately $30 \%$ at Wisconsin in 2011, 20\% at Illinois in 2010, 29\% at Iowa in 2010, and 32 and 30\% at Ohio in 2010 and 2012, respectively. These disease severities ranged from 0.2 to $0.3 \%$ in Wisconsin in 2011 to 16.7 to $22.1 \%$ in Illinois in 2010 . The untreated control had significantly lower yield $(P<0.05)$ than the fungicide-treated in three site-years. Fungicide application increased the yield by approximately $6 \%$ at Ohio in $2010,5 \%$ at Wisconsin in 2010 and $6 \%$ in 2011. Yield differences ranged from 8,403 to $8,890 \mathrm{~kg} / \mathrm{ha}$ in Wisconsin 2011 to 11,362 to $11,919 \mathrm{~kg} / \mathrm{ha}$ in Wisconsin 2010 . Results suggest susceptibility to disease and prevailing environment are important drivers of observed differences. Yield increases as a result of the physiological benefits of plant health benefits under low disease were not consistent.
\end{abstract}

During the past decade, maize (Zea mays L.) production in the U.S. Corn Belt has seen an increase in the use of foliar fungicides (Munkvold et al. 2008). Previously, the application of foliar fungicides to maize was rare, since the yield response was not sufficient to economically offset the cost of the fungicide (Munkvold et al. 2001; Paul et al. 2011; Wegulo et al. 1997). In recent years, however, high grain prices have led to increased land area under maize production. Purported yield enhancement associated with quinone outside inhibitors (QoI; sometimes referred to as strobilurins) have encouraged the use of foliar fungicides (Bradley 2012).

Maize is susceptible to several foliar fungal spot and blight diseases (Balint-Kurti and Johal 2009; White 1999), including gray leaf spot (GLS), caused by Cercospora zeae-maydis, (anamorph) and northern corn leaf blight (NCLB), caused by Setosphaera turcica - teleomorph (Exserohilum turcicum - anamorph). Traditionally, resistant hybrids or cropping practices, such as crop rotation and tillage, have been successfully used to manage these diseases. However, over the past two decades, minimal rotation and reduced or no-tillage have increased residue (Boosalis et al. 1986) and increased the risk of residue-borne disease-driven yield loss in maize, thus leading to greater interest in foliar fungicides (Wise and Mueller 2011). While fungicide use on corn was rare prior to 2002, and unreported by the U.S. Department of Agriculture until 2005, Munkvold et al. (2008) estimated fungicide use at approximately $18 \%$ of acreage planted in the major corn producing states in that year. In 2010 the

Corresponding author: S. Mallowa; E-mail address: sallymallowa@gmail.com

*The $\boldsymbol{e}$-Xtra logo stands for "electronic extra" and indicates that one supplementary table is published online.

http://dx.doi.org/10.1094/PHYTO-08-14-0210-R

(C) 2015 The American Phytopathological Society fungicide-sprayed acreage was estimated to be approximately $10 \%$ of acreage planted (Battaglin et al. 2011; Munkvold et al. 2001, Munkvold et al. 2008; Wise and Mueller 2011).

The decision to apply a foliar fungicide to maize is usually based on the developmental stage of the crop, environmental factors, the susceptibility of the host, and disease severity (Nelson and Meinhardt 2011). The effectiveness of such applications largely depends on their timing (Ward et al. 1997). Current recommendations are for application of foliar fungicides to maize at anthesis-crop development stages VT to R1 (Abendroth et al. 2011). These are based on the use of a measure that leads to the defining of characteristics for when to spray, i.e., a disease threshold of $5 \%$ severity on the third leaf below the ear leaf and above on $50 \%$ of the plants in the field at anthesis (Munkvold 1997). The range of crop development stages VT to R1 covers tassel emergence, silking, pollination, and fertilization. Thus, the number of harvestable kernels is determined and is a function of conditions during this period (Abendroth et al. 2011). A fungicide application at the R2/R3 (blister/milk) crop developmental stages provides protection from fungal infection to the leaves in the upper canopy and ensures their continued photosynthetic activity through to the R4/R5 (Munkvold 1997) crop developmental stages while grain fill takes place (Abendroth et al. 2011). Most of the VT/R1 threshold-based fungicide application guidelines were developed in the 1990s for DeMethylation Inhibitor (DMI) fungicides (Munkvold 1997; Munkvold et al. 2001). In the past decade, however, several new classes of fungicides with different modes of action, including strobilurin and succinate dehydrogenase inhibitor (SDHI) fungicides, have been registered for use on maize in the United States (Hewitt 1998).

Another factor responsible for increased fungicide use since 2007 is the marketing of strobilurins for yield enhancement in the absence of disease (Bartlett et al. 2002; Venâncio et al. 2003). Yield 
enhancement has been attributed to physiological effects (plant health benefits) related to greater water and nitrogen use efficiency (Ruske et al. 2003), increased antioxidant activity (Wu and Von Tiedemann 2002), delayed leaf senescence, and increased stand-ability of maize at harvest (Venâncio et al. 2003; Wise and Mueller 2011). Questions regarding the frequency of a positive yield response, economic benefit and justification for this use of fungicides, sometimes at the expense of other viable disease management options, however have been raised (Costa et al. 2012; Munkvold et al. 2001; Paul et al. 2011). In order to ensure sufficient sustainability, strobilurin fungicides should be part of an IPM system that minimizes the risk of development of resistant subpopulations of the pathogens being managed (Brent and Hollomon 2007; Vincelli 2002).

Paul et al. (2011) used meta-analysis to synthesize research findings from multiple individual trials (2002 to 2009) with multiple variables (hybrid, environment, trial design, and fungicides) on maize response to the most widely used foliar fungicides. These analyses indicated a positive yield response even at low disease though this was not always economically beneficial. Therefore, the objective of the current study was to develop a model within an IPM framework that could be used to determine how different disease intensities affect maize yield and how different management tactics (resistance and fungicide application) may mitigate these effects.

We hypothesized that depending on the maize hybrid and environment, foliar and stalk diseases may influence grain yield individually or in combination. This effect of diseases on yield may in turn influence the economic value of using a foliar fungicide. To test these hypotheses, coordinated field experiments were conducted in Illinois, Iowa, Ohio, and Wisconsin. The novelty of our approach was in the use of the same hybrids, fungicide, and its application timing and inoculation at all locations with the specific objectives of investigating (i) the effects of fungicide application timing on the intensities of foliar disease and stalk rot development and (ii) yield response in hybrid maize with varying levels of resistance to foliar diseases.

\section{MATERIALS AND METHODS}

Multistate field trials were established from 2010 to 2012 at the following locations: University of Illinois Crop Sciences Research and Education Center near Champaign, IL in 2010 and 2011 $\left(40^{\circ} 06^{\prime} 11.62^{\prime \prime},-88^{\circ} 23^{\prime} 55.36^{\prime \prime}\right)$, Iowa State University South Woodruff Farm near Napier, IA in 2010 and 2011 (41 ${ }^{\circ} 98^{\prime} 00.39^{\prime \prime}$, $\left.-93^{\circ} 69^{\prime} 34.73^{\prime \prime}\right)$, University of Wisconsin Arlington Agricultural Research Station near Arlington, WI in 2010 and 2011 (43 $18^{\prime} 56.02^{\prime \prime}$, $\left.-89^{\circ} 19^{\prime} 58.30^{\prime \prime}\right)$, the Ohio State University Beef and Sheep Research Unit, Wooster, $\mathrm{OH}$ in 2010, $\left(40^{\circ} 71^{\prime} 83.3^{\prime \prime}, 81^{\circ} 89^{\prime} 45.05^{\prime \prime}\right)$, and Western Agricultural Research Station near South Charleston, $\mathrm{OH}$ in $2012\left(39^{\circ} 86^{\prime} 02.01^{\prime \prime}, 83^{\circ} 67^{\prime} 01.21^{\prime \prime}\right)$. Trials were planted between days 125 and 139 of the year (5 to 20 May), with the exception of the trial at Wooster, $\mathrm{OH}$ in 2010, which was planted on day 145 (25 May) of the year (Table 1). Rainfall, relative humidity (\%), and daily temperature data for the months of May to October for all siteyears were downloaded from the NOAA website for the airport nearest to the location (accessed 20 September 2013). Data on the 30-year average (normal) (Environment Canada, 2011) for the same parameters was also noted.

All trials were established in no to minimum-tilled fields planted with maize the previous growing season, mimicking a conservationtillage/continuous-maize cropping system. Trials were managed according to local University extension recommendations related to agronomic practices (Dodd 1980; Mueller and Sisson 2013; Nafziger 2009; Thomison et al. 2005). The experimental design was a randomized complete block with split-split-plot arrangement of hybrid, fungicide treatment, and inoculation in four replicate blocks. The whole plot treatment was hybrid (four levels; two levels in Ohio 2012), the subplot was fungicide application timing (four levels), and the sub-subplot was inoculation treatments (10 levels), hereafter referred to as the plot. Each plot consisted of four 7.62-mlong rows, spaced $76.2 \mathrm{~cm}$ apart. There were a total of 640 plots at each site-year, except for Ohio 2012 with 320 plots.

Four yellow dent corn hybrids, differing in levels of partial resistance to GLS and multigenic resistance to NCLB, were obtained from DuPont Pioneer Hi-Bred International (Johnston, IA): (i) 'P0461XR' (104 days to comparative relative maturity [CRM 104 days], and susceptible to GLS and NCLB, (ii) 'P0891XR' (CRM 108 days and resistant to GLS and NCLB), (iii) 'P35F44' (CRM 105 days, resistant to NCLB and susceptible to GLS), and (iv) 'P33W84' (CRM 111 days, resistant to GLS and susceptible to NCLB). All four hybrids were planted in all site-years, except for Ohio in 2012 when only 'P0891XR' and 'P0461XR' were planted.

The following fungicide treatments were evaluated: an untreated control (UTC), a single application of Headline (pyraclostrobin, BASF, Research Triangle Park, NC) made (i) between anthesis and silking (VT/R1) stages (Abendroth et al. 2011), or (ii) between blister and milk (R2 to R3, respectively) stages, or (iii) using a foliar disease severity threshold $(\mathrm{T})$. The threshold-based applications were made when GLS or NCLB lesions were observed on the third leaf below the ear or above on $50 \%$ of the plants in the subplot (Munkvold 1997). At the Ohio location in 2010, there were three replicates of the threshold treatment, while in Wisconsin trial in 2011, no threshold treatment was applied since the threshold was not observed; therefore, this treatment was considered as another replication of the untreated control.

Each subplot was divided into 10 four-row plots that were inoculated with different combinations of $C$. zeae-maydis and $S$. turcica between crop development stages V6 and V12 to ensure pathogen presence and increase the chances of infection. In Iowa and Ohio, plots were inoculated either at V6, V9, or at both V6 and V9, whereas in Illinois and Wisconsin, plots were inoculated either at V9, V12, or at both V9 and V12. Inoculation treatments consisted of noninfested sterilized grain (UTC), sterilized grain infested with C. zeae-maydis alone, $S$. turcica alone, or a 1:1 mixture of sterilized grain infested with $C$. zeae-maydis and $S$. turcica. Inoculum was prepared as previously described (Venâncio et al. 2003), using sorghum (Sorghum bicolor) as the carrier, except in Ohio where white millet (Panicum miliaceum) was used (Wallhead 2012). Approximately 18 to 20 kernels of infested grain inoculum were dispensed into the whorl of

TABLE 1. Main trial information, Julian day (JD) when the trial was planted and days after planting when disease assessment and fungicide application was done in the field trials conducted between 2010 to 2012 (bold values correspond to observation dates used in the analysis)

\begin{tabular}{|c|c|c|c|c|c|c|c|c|c|}
\hline \multirow[b]{2}{*}{ Site } & \multirow[b]{2}{*}{ Year $^{\text {b }}$} & \multirow[b]{2}{*}{ JD } & \multicolumn{3}{|c|}{$\begin{array}{c}\text { Disease } \\
\text { assessments } \\
\text { (days after } \\
\text { planting) }\end{array}$} & \multicolumn{4}{|c|}{$\begin{array}{l}\text { Fungicide application } \\
\text { (days after planting) }^{\mathrm{a}}\end{array}$} \\
\hline & & & 1 & 2 & 3 & VT/R1 & R2/R3 & $\mathrm{T}$ & $\mathrm{T}^{\mathrm{c}}$ \\
\hline \multirow[t]{2}{*}{ Illinois } & 2010 & 125 & 79 & 93 & NA & 70 & 78 & 92 & \\
\hline & 2011 & 132 & 67 & 81 & 105 & 64 & 75 & 81 & \\
\hline \multirow[t]{2}{*}{ Iowa } & 2010 & 139 & 57 & 71 & 92 & 63 & 77 & 84 & \\
\hline & 2011 & 139 & 55 & 76 & 105 & 68 & 82 & 57 & 71 \\
\hline \multirow[t]{2}{*}{ Ohio } & 2010 & 145 & 80 & NA & NA & 64 & 96 & 71 & 78 \\
\hline & 2012 & 126 & 116 & NA & NA & 72 & 87 & 97 & \\
\hline \multirow[t]{2}{*}{ Wisconsin } & 2010 & 125 & 55 & 86 & 110 & 62 & 86 & 90 & \\
\hline & 2011 & 127 & 95 & 103 & 109 & 59 & 90 & NA & \\
\hline
\end{tabular}

a Strobilurin fungicide used was Headline (pyraclostrobin), BASF, Research Triangle Park, NC. Treatments were as follows: UTC, an untreated control; VT/R1, single application of strobilurin fungicide applied at anthesis; R2/R3, single application applied at blister/milk growth stage; and T, single application applied based on a threshold foliar disease severity defined as $5 \%$ disease severity on the third leaf below the ear leaf or above on $50 \%$ of the plants in the plot.

b The trial was repeated in 2011 in Iowa, Illinois, and Wisconsin and 2012 in Ohio.

c In Iowa 2011 and Ohio 2010 sites, disease in some threshold plots developed later and consequently these plots were sprayed later. 
each plant in the two center rows of each plot at the appropriate crop development stages.

Foliar disease severity assessments. Foliar disease severity was assessed in all plots. The number of disease assessments varied by trial, ranging from a single assessment in both years in Ohio, two in Illinois in 2010, and three at all other site-years. The date and growth stage at which disease severity was assessed also varied among sites (Table 1), ranging from 55 to 116 days after planting (dap), which corresponded to crop developmental stages R1 and R5, respectively. For the purpose of data analysis and treatment comparison, disease assessment data from 80 to 93 dap (approximate crop developmental stage early R5) were used in 2010, and 103 and 116 dap (approximate crop developmental stage mid to late R5) in 2011 and 2012. Plots were evaluated by quantifying disease severity (percent leaf area covered with lesions) on the ear leaf, one leaf above the ear leaf and one leaf below the ear leaf. Severity of NCLB and GLS were assessed separately in both years in Iowa and Wisconsin, and in 2010 in Ohio. Notes were taken on several other foliar diseases including anthracnose leaf blight (caused by Colletotrichum graminicola), common rust (caused by Puccinia sorghi), and eyespot (caused by Kabatiella zeae) (data not shown). In Illinois in 2010 and 2011, and Ohio in 2012, a composite measure of disease severity was done by quantifying the percent leaf area covered by lesions of all foliar diseases present; NCLB was the predominant disease in Ohio in 2012.

Stalk rot assessments. At physiological maturity (R6), stalk rot severity was estimated on three or six consecutive plants in each of the two center rows of each plot, depending on state. Plants in each plot were destructively sampled and split longitudinally from the ear down to the soil line and stalk rot severity was assessed using a 0 to 5 rating scale $(0=$ no stalk rot evident and $5=$ complete destruction of the pith with lodging below the ear), similar to that used by Hines (2007). Assessments of plots were made on a conditional basis meaning that control plots were assessed first. If stalk rot severity was, on average, equal to a rating of 2 or higher, the rest of the plots were assessed, and if not, no further assessments were made. All plots were scored at Iowa in 2010, at Illinois in 2010 and 2011, and only control plots were rated at Iowa in 2011, at Ohio in 2010, and at Wisconsin in 2010.

Yield assessments. After physiological maturity (crop developmental stage R6), the remaining plants in the two center rows of each plot were harvested using a plot combine with a scale and grain moisture sensor installed. Yields were converted to kilograms per hectare and were standardized to $15.5 \%$ moisture.

Statistical analyses. Data were analyzed using PROC GLIMMIX of SAS v. 9.2 (SAS Institute, Cary, NC) (Littell et al. 2006) to examine the effect of the different treatments on both disease severity and yield. Exploratory analyses indicated large variations across trials; therefore, each individual site-year was analyzed separately. For all analyses the level of significance was set to $5 \%(\alpha=0.05)$ and Fisher's protected least significant difference (LSD) was used to compare treatments. Furthermore, when significant interactions were found, the SLICE option in SAS was used to examine these at the level of each main effect. Graphical methods including boxplots and histograms were used to visualize means stratified by hybrid, fungicide, inoculation, and/or their interactions. Correlation was tested for the association between foliar disease and stalk rot. Results from the exploratory analysis showed that the use of a square-root or logit transformation did not reduce the overdispersion of zero's observed in scores for the two diseases (GLS and NCLB). Therefore, disease severity data were analyzed without transformation. For final models, hybrid, fungicide timing, and inoculation were considered fixed effects, while replication and whole plot and subplot errors were considered random effects. Due to missing observations, degrees of freedom were calculated based on the Kenward-Rogers method (Littell et al. 2006).

\section{RESULTS}

Weather data summary. The average monthly trends during the period of each trial for rainfall, temperature, and relative humidity are presented in Table 2 . The 30 -year average (normal) weather data used in this study were from weather stations near each site. Emphasis was placed on July and August when fungicide application and most disease ratings were done. Temperature averages ranged from 22.8 to $25.0^{\circ} \mathrm{C}$ in July and August 2010, and between 18.6 and $25.6^{\circ} \mathrm{C}$ in July and August 2011. Rainfalls were normal, except for Wisconsin 2010 with $203 \mathrm{~mm}$ in July and Iowa 2010 with $381 \mathrm{~mm}$ in August that were above normal, while in Illinois 2011 August rainfall at $37 \mathrm{~mm}$ was below average.

In 2010, the temperature in June and July was near normal, while in August, September, and October temperatures were above normal across the four states, except for Wisconsin where an early frost occurred. In June 2010, rainfall was above normal in Iowa and some plots flooded resulting in uneven growth in the trial. In August, rainfall was above normal in Iowa and Wisconsin. The second year of the study started with above normal rainfall in Iowa, Illinois, and Ohio in May; however, it was $75 \%$ of the normal in Wisconsin. In Iowa and Illinois the rainfall was above normal in June and below normal in Ohio. July was drier than normal at all sites and this continued through August in Iowa and Illinois; however the rainfall was above normal in Wisconsin and normal in Ohio.

At all locations, June temperatures were slightly below normal. Conditions in July throughout the region were warmer than normal, and this trend continued through September. Warm windy conditions were prevalent at all locations in October. The 2012 growing season in Ohio was characterized by warm and dry conditions, and the daily mean temperature $\left(25.5^{\circ} \mathrm{C}\right)$ in July was the warmest since 1934.

Foliar disease. The total mean severity of both diseases (GLS and NCLB) was combined for the different treatments. There were no statistically significant three-way interactions of fixed effects at any site-year, nor two-way interactions of fungicide application by inoculation, and hybrid by fungicide application observed for the disease severity (Table 3 and Supplementary Table S1). However, a significant effect of the hybrid by inoculation interaction on disease was observed at Illinois in 2010, at Ohio in 2010, and at Ohio in $2012(P<0.0001, P<0.0001$, and $P=0.0012$, respectively). Hybrid 'P0461XR' (susceptible to both GLS and NCLB) when inoculated with both pathogens consistently had higher disease severity than the other hybrid by inoculation combinations. At Illinois in 2010, the noninoculated control had the lowest levels of disease, significantly lower than in the inoculated treatments for all the hybrids. At Ohio in $2010(P<0.0001)$, there was no significant difference in mean disease severity between $C$. zeae-maydis inoculated treatments ('P35F44' 1.1\%, 'P33W84' 0.2\%, 'P0461XR' $0.7 \%$, and 'P0891XR' $0.5 \%$ ) and noninoculated treatments for any hybrid ('P35F44' $0.2 \%$, 'P33W84' $0.1 \%$, 'P0461XR' $0.4 \%$, and 'P0891XR' 0.1\%). However, inoculation with $S$. turcica resulted in significantly higher mean disease severity ('P35F44' $6.4 \%$, 'P33W84' 4.9\%, 'P0461XR' $8.0 \%$, and 'P0891XR' 1.6\%) when compared with the noninoculated control or plants inoculated with C. zeae-maydis alone. Similarly, at Ohio in $2012(P=0.0012)$, the noninoculated control had less disease in two of the hybrids, 'P0461XR' (4.3\%) and 'P0891XR' (2.3\%), although this treatment was only significantly different from the inoculation treatment with both $C$. zeae-maydis and $S$. turcica pathogens in hybrid 'P0461XR' with susceptibility to both GLS and NCLB $(11.9 \% ; P=0.0012)$ (Fig. 1).

Table 3 summarizes $P$ values from fixed effects in all site-years. Trials in which $P<0.05$ are bolded indicate differences in treatments and thus emphasize factors that could drive interactions observed. In the case of Illinois in 2010, Ohio in 2010, and Ohio in 2012, hybrid, fungicide, and inoculation affected disease severity. 
A significant effect of fungicide on disease was observed at Iowa in $2010(P=0.0304)$ and at Wisconsin in $2011(P=0.0396)$. Inoculation had a significant effect on severity at Iowa in $2011(P=$ $0.0477)$. In 2010, mean foliar disease severity across hybrids was low $(<5 \%)$ in Iowa, Ohio, and Wisconsin but considerably higher in Illinois (11 to $30 \%)$. In the second year foliar disease severity ranged from 2 to $23 \%$ at Illinois in 2011; however it was generally lower, $<2 \%$, across all treatments at Iowa in 2011, at Wisconsin in 2011, and at Ohio in 2012, (Fig. 2).

Disease severity in all trials was generally low, $<25 \%$, in all sites. Fungicide application affected disease in Iowa $(P=0.0304)$, Illinois $(P<0.0001)$, and Ohio $(P=0.0491)$ in 2010 , Wisconsin $(P=$ $0.0396)$ in 2011, and Ohio $(P=0.0229)$ in 2012. The percent disease reduction was often quite small (Fig. 3). An application of fungicide at VT/R1 reduced disease severity more than those at R2 to R3, at disease threshold and the untreated control (Iowa, 1.0, 1.3, 1.3, and 1.4\%; Illinois, 16.7, 21.1, 22.1, and 20.9\%; and Ohio, 1.5, 2.0, 2.0, and 2.2\%, respectively) (Iowa, 1.4\%; Illinois, 20.9\%; and Ohio, 2.2\%). Similarly at Wisconsin in 2011 and at Ohio in 2012, the highest mean disease severity was observed in the untreated control
(Wisconsin $0.3 \%$, Ohio $5.7 \%$ ) compared with the fungicide applied at VT/R1 (Wisconsin $0.2 \%$, Ohio $4.0 \%$ ) (Fig. 3).

Stalk rot. Stalk rot assessments were made in all plots at Iowa in 2010, Illinois in 2010 and Illinois in 2011. The disease estimate in control treatments was extremely low and did not justify proceeding with further rating in any plots at Wisconsin in 2011 and at Ohio in 2012. There was no association between stalk and foliar diseases as only 1 to $3 \%$ of the variation in stalk rot could be predicted by the foliar disease (data not shown). There was no effect of fungicide application on stalk rot severity $(P=0.6000)$ at Iowa in 2010; however, fungicides applied at the VT/R1 stage reduced stalk rot severity at Illinois in $2010(P=0.0002)$ and at Illinois in $2011(P=$ 0.0441 ) (Table 4). Hybrid affected stalk rot at Illinois in 2011, where stalk rot ratings averaged 2; the hybrid 'P0891XR', which is resistant to GLS and NCLB, had a statistically higher score than the other hybrids (Table 5).

Yield. Grain yields were generally higher in 2011 and 2012 than in 2010 in Iowa, Illinois and Ohio locations (Figs. 4 and 5). There was an interaction of hybrid by fungicide application on yield at only one site-year, Wisconsin $2011(P=0.005)$ (Table 6), where

TABLE 2. Monthly averages of weather data from National Climatic Data Center for four sites between 2010 and 2012

\begin{tabular}{|c|c|c|c|c|c|c|c|c|c|}
\hline \multirow[b]{2}{*}{ Month } & \multirow[b]{2}{*}{ Weather variable ${ }^{\mathrm{b}}$} & \multicolumn{4}{|c|}{$2010^{\mathrm{a}}$} & \multicolumn{4}{|c|}{$2011 / 2012^{\mathrm{a}}$} \\
\hline & & IA & IL & $\mathrm{OH}$ & WI & IA & IL & $\mathrm{OH}$ & WI \\
\hline \multirow[t]{4}{*}{ May } & PPT & 89 & 81 & 116 & $95(7)$ & 142 & 110 & 65 & $61(27)$ \\
\hline & Days & 13 & 15 & 16 & 9 & 12 & 13 & 4 & 12 \\
\hline & $\mathrm{RH}$ & 54.1 & 57.5 & 56.9 & 53.8 & 54.0 & 56.8 & 52.8 & 51.5 \\
\hline & $\mathrm{T}$ & 15.9 & 17.8 & 16.8 & $15.8(2.7)$ & 15.7 & 16.9 & 18.1 & $13.7(-0.7)$ \\
\hline \multirow[t]{4}{*}{ June } & PPT & 312 & 224 & 171 & $213(97)$ & 5 & 89 & 47 & $90(23)$ \\
\hline & Days & 23 & 19 & 15 & 14 & 11 & 13 & 9 & 10 \\
\hline & $\mathrm{RH}$ & 66.4 & 69.3 & 65.2 & 63.6 & 65.0 & 66.4 & 60.8 & 62.1 \\
\hline & $\mathrm{T}$ & 21.8 & 23.2 & 21.3 & $20.0(1.6)$ & 25.6 & 26.4 & 18.6 & $20.2(1.3)$ \\
\hline \multirow[t]{4}{*}{ July } & PPT & 78 & 97 & 79 & $203(3.8)$ & 74 & 20 & 84 & $47(-58)$ \\
\hline & Days & 4 & 10 & 9 & 13 & 17 & 2 & 13 & 10 \\
\hline & $\mathrm{RH}$ & 70.5 & 71 & 67.8 & 68.4 & 73.4 & 73.0 & 68.0 & 69.6 \\
\hline & $\mathrm{T}$ & 23.8 & 25.0 & 22.8 & $23.7(-2.33)$ & 25.6 & 26.4 & 23.7 & $24.8(5.4)$ \\
\hline \multirow[t]{4}{*}{ Aug } & PPT & 381 & 54 & 83 & $99(90)$ & 76 & 37 & 59 & $78(30)$ \\
\hline & Days & 16 & 10 & 7 & 5 & 10 & 5 & 11 & 10 \\
\hline & $\mathrm{RH}$ & 70.1 & 70.0 & 66.5 & 69.6 & 67.0 & 66.9 & 62.0 & 65.0 \\
\hline & $\mathrm{T}$ & 23.9 & 24.7 & 22.0 & $24.8(5.4)$ & 22.1 & 23.3 & 20.0 & $21.8(2.0)$ \\
\hline \multirow[t]{4}{*}{ September } & PPT & 126 & 67 & 67 & $67(11)$ & 43 & 66 & 13 & $84(8)$ \\
\hline & Days & 16 & 12 & 10 & 11 & 7 & 13 & 1 & 8 \\
\hline & $\mathrm{RH}$ & 58.3 & 59.7 & 57.1 & 56.2 & 54.6 & 57.0 & 55.6 & 54.4 \\
\hline & $\mathrm{T}$ & 17.6 & 19.7 & 17.3 & $16.2(0.1)$ & 15.7 & 17.6 & 15.7 & $15.0(-2.0)$ \\
\hline \multirow[t]{4}{*}{ October } & PPT & 10 & 31 & 41 & $58(3)$ & 25 & 51 & 173 & $34(-25)$ \\
\hline & Days & 4 & 4 & 11 & 4 & 5 & 9 & 12 & 8 \\
\hline & $\mathrm{RH}$ & 46.6 & 47.9 & 46.3 & 46.1 & 46.0 & 47 & 46.8 & 46.3 \\
\hline & $\mathrm{T}$ & 12.0 & 12.8 & 11.2 & $11.2(3.3)$ & 11.7 & 12.0 & 10.6 & 11.3 \\
\hline
\end{tabular}

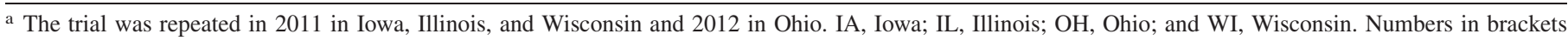
indicate the departure from normal.

b PPT, precipitation (rainfall); Days, number of days with rainfall more than $2.54 \mathrm{~mm}$; RH, relative humidity (\%); and T, temperature in degrees Celsius.

TABLE 3. $P$ values summarizing all fixed effect factors related to disease severity $(\%)$ per whole plot at four sites between 2010 and 2012

\begin{tabular}{|c|c|c|c|c|c|c|c|c|}
\hline \multirow[b]{2}{*}{ Factors $^{b}$} & \multicolumn{4}{|c|}{$2010^{\mathrm{a}}$} & \multicolumn{4}{|c|}{$2011 / 2012^{\mathrm{a}}$} \\
\hline & IA & IL & $\mathrm{OH}$ & WI & IA & IL & $\mathrm{OH}^{\mathrm{c}}$ & $\mathrm{WI}^{\mathrm{d}}$ \\
\hline Hybrid & 0.2551 & $<0.0001$ & $<0.0001$ & 0.3678 & 0.9176 & 0.7350 & 0.0558 & 0.7196 \\
\hline Fungicide & 0.0304 & $<0.0001$ & 0.0491 & 0.7273 & 0.1457 & 0.9370 & 0.0229 & 0.0396 \\
\hline $\mathrm{H} \times \mathrm{F}$ & 0.6622 & 0.4712 & 0.9590 & 0.4571 & 0.8357 & 0.2624 & 0.8431 & 0.2077 \\
\hline Inoculation & 0.4714 & $<0.0001$ & $<0.0001$ & 0.7388 & 0.0477 & 0.9556 & $<0.0001$ & 0.2486 \\
\hline $\mathrm{H} \times \mathrm{I}$ & 0.2448 & $<0.0001$ & $<0.0001$ & 0.4957 & 0.9710 & 0.5040 & 0.0012 & 0.3314 \\
\hline $\mathrm{F} \times \mathrm{I}$ & 0.7172 & 0.1040 & 0.5801 & 0.5768 & 0.4059 & 0.0566 & 0.9741 & 0.7729 \\
\hline $\mathrm{H} \times \mathrm{F} \times \mathrm{I}$ & 0.4253 & 0.4896 & 0.9135 & 0.6453 & 0.7010 & 0.2430 & 0.0900 & 0.9685 \\
\hline
\end{tabular}

a The trial was repeated in 2011 in Iowa, Illinois, and Wisconsin and 2012 in Ohio. IA, Iowa; IL, Illinois; OH, Ohio; and WI, Wisconsin.

b Main effects and their interactions: H, hybrid; F, fungicide; and I, inoculation.

c Ohio 2012, only two hybrids were evaluated 'P0461XR' and 'P0891XR'.

d Wisconsin 2011, no threshold fungicide application. 
greater yields were measured on 'P33W84' and 'P0461XR' with fungicide applied at VT/R1 or at R2 to R3 compared with the untreated control. At this same location, an R2 to R3 fungicide application on 'P0891XR' also resulted in greater yields than the control (data not shown). Hybrid by inoculation affected yield in only one site-year, Illinois in $2011(P=0.0089)$ (Table 6), where hybrids with resistance to NCLB consistently yielded better than the susceptible hybrids, and treatments that had inoculations with $S$. turcica at two different times had lower yields.

In 2010, fungicide application affected yield in Illinois $(P=$ $0.0320)$, Ohio $(P=0.0199)$, and Wisconsin $(P<0.0001)$. The untreated control yielded lower than fungicide-treated plots in Illinois, Ohio, and Wisconsin (Table 1). There were no differences with regard to application timing for these fungicide-treated plots. Similarly, at
Wisconsin in $2011(P=0.0012)$, the fungicide treatments yielded more than the untreated control, but were not different from each other (Fig. 4).

Yield varied by hybrid at Wisconsin in $2010(P=0.0011)$ and at Iowa in $2011(P=0.0164)$ (Fig. 5). The hybrid with resistance to GLS, 'P33W84', had the highest yields at Wisconsin in 2010 and at Iowa in 2011, while hybrid 'P0461XR' with susceptibility to both GLS and NCLB had the lowest yields. At Illinois in 2011, 'P35F44', with resistance to NCLB, had the greatest yield compared with the other hybrids $(P=0.0264)$ that were not different from each other.

\section{DISCUSSION}

We evaluated the use of foliar fungicides on corn in standardized trials conducted in different environments across four states in the
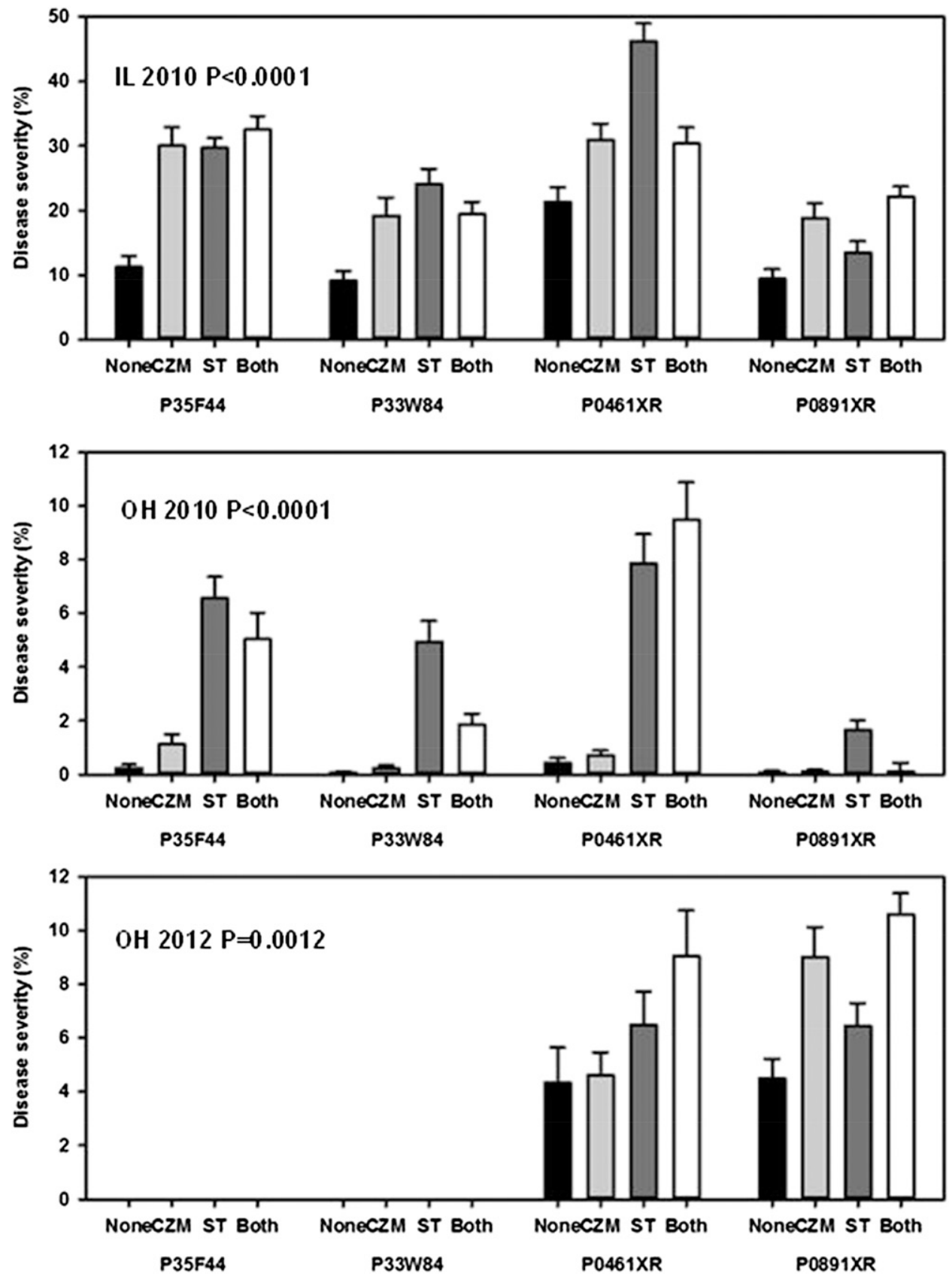

Fig. 1. Effect of hybrid and inoculation (with pathogen Cercosposa zeae-maydis [CZM] or Setosphaera turcica [ST] or None or Both) on gray leaf spot (GLS) and northern corn leaf blight (NCLB) combined disease severity (\%) assessed at the R4/R5 crop developmental stage, on the ear leaf of four maize hybrids ('P35F44', resistant to NCLB; 'P33W84', resistant to GLS; 'P0461XR', susceptible to both GLS and NCLB; and 'P0891XR', resistant to both GLS and NCLB) grown at three sites between 2010 and 2012 . 
U.S. Corn Belt. Our research is unique because we used the same hybrids, fungicide product, and application timings in all eight siteyears. Different hybrids, products, or application timing confounds previous research that assessed foliar fungicides on corn.

Despite inoculation at early growth stages to enhance disease development, final disease severity in six of the eight site-years was low and strongly influenced by environment and hybrids. In Illinois, variation in disease due to hybrid was moderate while variation related to fungicide application was low. Trials in which fungicide application yielded higher corn yields (statistically significant) did not necessarily always also have disease significantly lowered when a fungicide was applied compared with the nonsprayed control.

Our data indicated consistently lower disease severity on resistant (partial/incomplete) hybrids, even in situations where disease severity was considered very low $(<5 \%)$. Foliar diseases cause chlorosis and necrosis that reduce the photosynthetic ability of leaves. The use of foliar fungicides is most likely to be profitable when foliar disease severity is high (Paul et al. 2011). Nonetheless, while the protection from the application of a foliar fungicide is similar at low disease severity, meaning that the disease severity is reduced, economically it is not likely to be profitable and therefore has less direct impact on improving corn production (Johnson 1987). These results are similar to those observed in trials conducted between 2002 and 2009 in 14 states (Paul et al. 2011) where the differences in either disease or yield due to a fungicide application were highly variable among studies. In our trials, fungicide application reduced combined GLS and NCLB disease severity in four of the eight site-years, and an application made at VT/R1 was generally the most effective. These results are consistent with those reported by Nelson and Meinhardt (2011), who showed that the severity of GLS was reduced by an application of pyraclostrobin at VT in four out of six site-years and NCLB in one out of six siteyears.

The efficacy of a fungicide depends on application timing and is influenced by the amount of disease that is present in the fields (Coulter 2010; Wise and Mueller 2011). In our research, applications made between VTand R1 were the most effective in lowering disease severity under either low or moderate disease conditions. This concurred with previous recommendations for fungicide application in the United States (Munkvold and Gorman 2006). However, this reduction in disease did not consistently translate into a yield benefit. For example, in the 2010 and 2011 Illinois trials, where disease intensity was considered moderate, there was a reduction in disease severity with fungicide application, but differences in yield were not statistically significant $(P>0.05)$. A similar situation was observed at Iowa in 2010 trial, where disease severity was low and was reduced with fungicide application $(P=0.0304)$, but differences in yield were again not significant. One explanation could be due to disease onset occurring later in the growing season and therefore not impacting grain fill. In addition hybrids with resistance (incomplete/partial) to foliar diseases can withstand the diseases and show minimal impact on grain fill and yield even when foliar symptoms are present (Wallhead 2012). In our trial only 'P0461XR' had susceptibility to both GLS and NCLB, while the other hybrids had resistance to at least one of the diseases. In another study, Blandino et al. (2012) reported that earlier applications (V12 to V15, pre-VT) were effective at reducing NCLB when disease severity was high, while applications from VT to R3 were effective in reducing NCLB when disease severity was low. However, in that study only applications around VT significantly increased grain yield compared with an
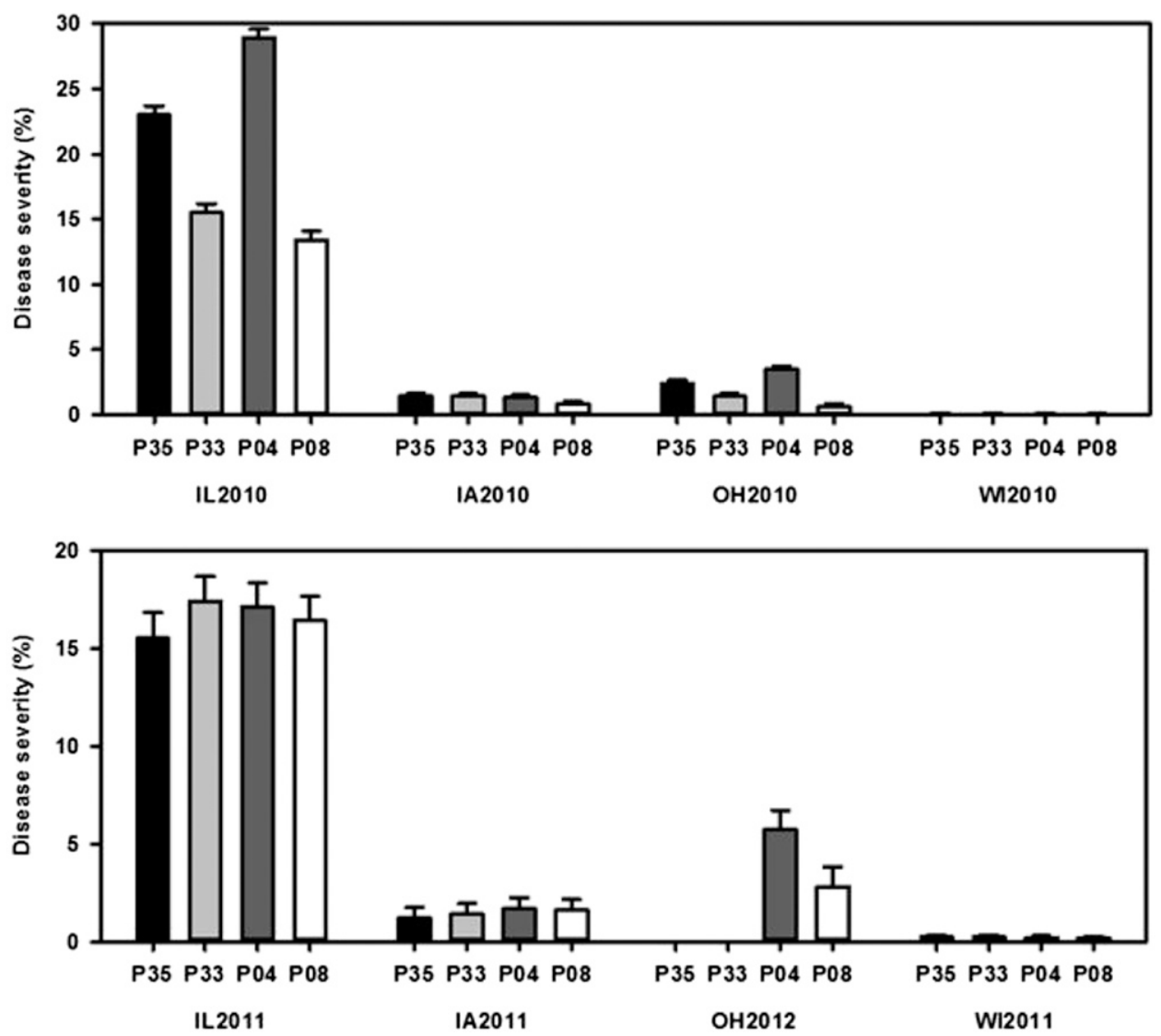

Fig. 2. Effect of hybrid on gray leaf spot (GLS) and northern corn leaf blight (NCLB) disease severity (\%) assessed at the R4/R5 crop developmental stage, on the ear leaf of four maize hybrids grown at four sites between 2010 and 2012. Trial was repeated in 2011 in Iowa, Illinois, and Wisconsin and 2012 in Ohio. All hybrids were from DuPont-Pioneer Hi-bred International, Inc. P35, 'P35F44', susceptible to GLS and resistant to NCLB; P33, 'P33W84', resistant to GLS and susceptible to NCLB; P04, 'P0461XR', susceptible to both GLS and NCLB; and P08, 'P0891XR', resistant to both GLS and NCLB. IA, Iowa; IL, Illinois; OH, Ohio; and WI, Wisconsin. Ohio 2012, only two hybrids were evaluated 'P0461XR' and 'P0891XR'. 
untreated control. This emphasizes the influence of the presence of disease and timing of application on the grain yield when making comparisons to untreated controls.

We did not consistently reduce disease when an application of fungicide was made at disease threshold (Munkvold 1997). These results were not affected by whether the threshold treatment was met for both diseases at the same time, or for individual diseases, as observed in 2010 at Ohio and in 2011 at Iowa. Shah and Dillard (2010), working with sweet corn in New York, reported that a threshold treatment of a strobilurin fungicide applied when $1 \%$ of a plot had foliar disease, reduced foliar disease by $8 \%$ compared with the control in a susceptible hybrid with up to $60 \%$ foliar disease severity, but there was no yield benefit. The inconsistencies between our work and that of Shah and Dillard (2010) could be due, in part, to the higher susceptibility of sweet corn to foliar disease or the threshold being conservative. The disease threshold for fungicide application is an area of research that warrants further investigation.

The risk of GLS is affected by planting date and consequently crop growth stage relative to favorable weather (Bhatia and Munkvold 2002; Paul and Munkvold 2005); thus, final GLS severity may be greater on late planted maize compared with maize planted at the recommended planting time. Growers in the Corn Belt are planting earlier compared with the past (Elmore 2013); consequently crops often reach reproductive stages before late July to early August when weather conditions are more favorable for foliar disease development. Decisions on fungicide application timing should take into consideration the environment in the current growing season and the crop developmental stage, so that the fungicide effective period overlaps with when the weather is favorable for disease. It has been suggested that fungicide application could lead to economic losses if done when disease risk is low (Paul et al. 2011). In our trials, in three of eight site-years, we observed an increase in yield when foliar fungicides were applied in the absence of disease control (Illinois 2010, Wisconsin 2010, and Ohio 2012). QoI fungicides in the U.S. Corn Belt have been labeled for yield enhancing plant health benefits (Nelson and Meinhardt 2011). Others have reported greater yields in the absence of disease or

TABLE 4. Effect of fungicide on stalk rot disease of corn ( 0 to 5 scale) assessed at the R6 physiological maturity crop developmental stage, on the stalks of four maize hybrids grown in Iowa and Illinois between 2010 and 2012

\begin{tabular}{lccc}
\hline & $2010^{\mathrm{a}}$ & 2010 & $\frac{2011}{\mathrm{n}}$ \\
\cline { 2 - 3 } Fungicide $^{\mathrm{b}}$ & $\mathrm{IA}$ & 2.16 & $\mathrm{IL}$ \\
\hline $\mathrm{UTC}$ & 1.73 & 1.89 & 2.06 \\
VT/R1 & 1.67 & 2.03 & 1.83 \\
$\mathrm{R} 2$ & 1.70 & 2.07 & 2.04 \\
$\mathrm{~T}$ & 1.67 & 0.11 & 1.67 \\
LSD & $\mathrm{NS}$ & 0.0002 & $\mathrm{NS}$ \\
$P$ value & 0.8531 & 0.0441 \\
\hline
\end{tabular}

a Results are presented for stalk rot ratings done in 2010 in Iowa and Illinois and in 2011 only in Illinois. IA, Iowa; and IL, Illinois.

b Strobilurin fungicide used was Headline (pyraclostrobin), BASF, Research Triangle Park, NC. Treatments were: UTC, an untreated control; VT/R1, single application of strobilurin fungicide applied at anthesis; R2/R3, single application applied at blister/milk growth stage; and $\mathrm{T}$, single application applied based on a threshold foliar disease severity defined as $5 \%$ disease severity on the third leaf below the ear leaf or above on $50 \%$ of the plants in the plot.
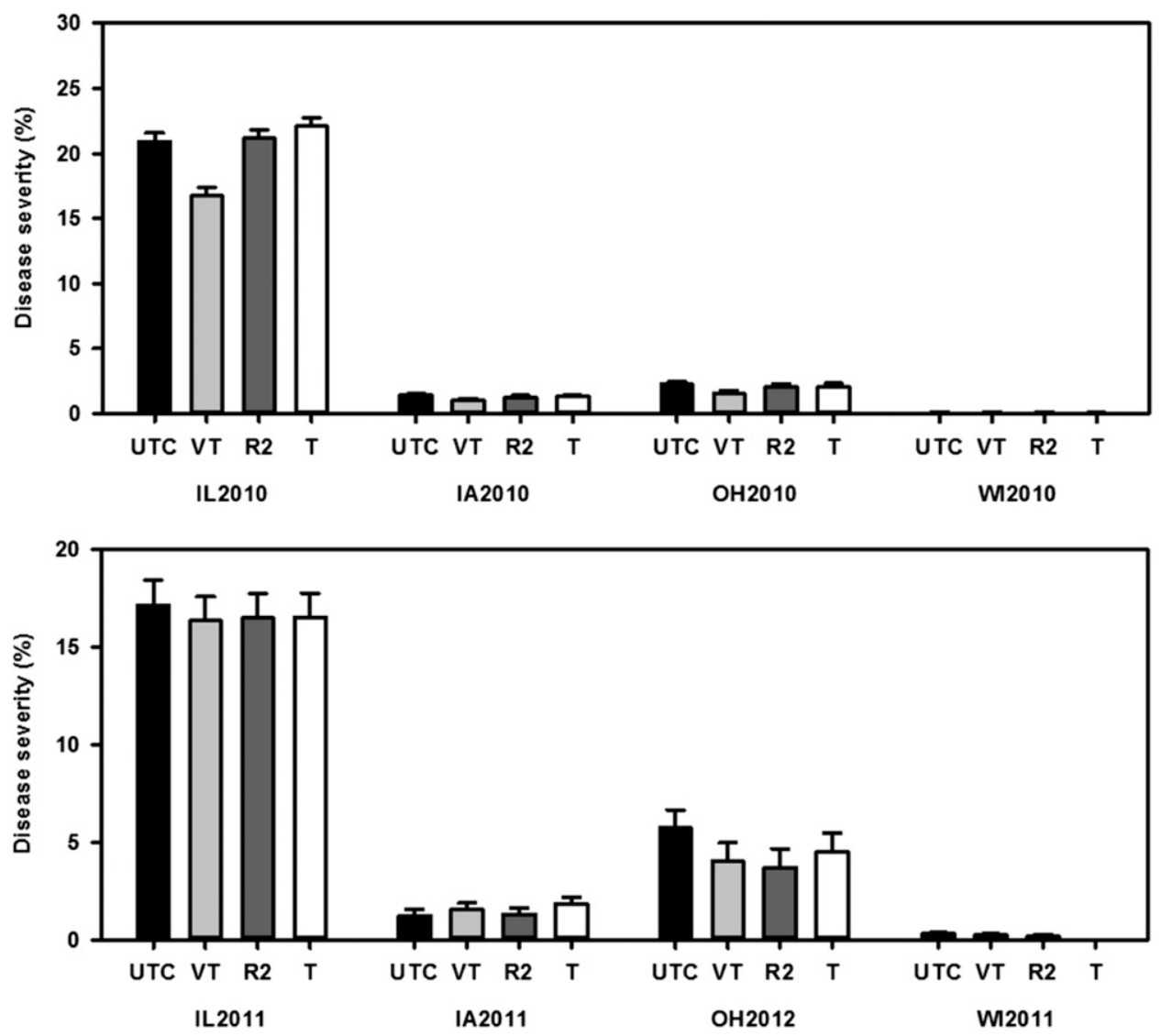

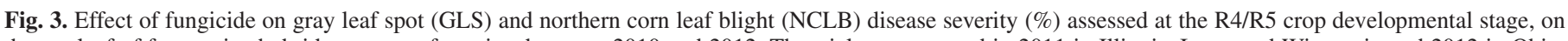

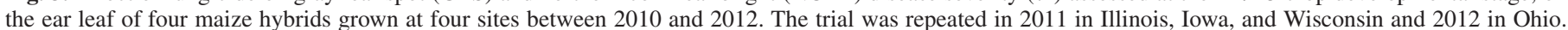

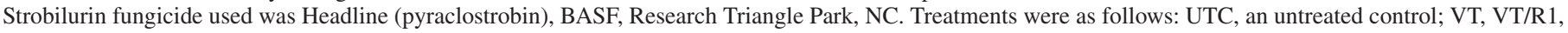

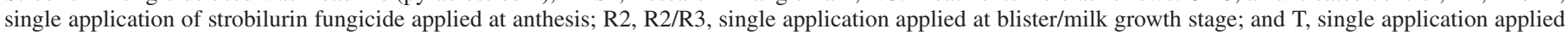

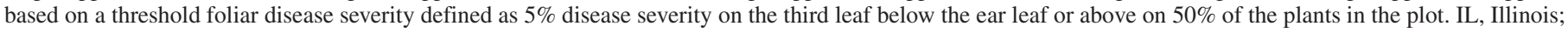
IA, Iowa; OH, Ohio; and WI, Wisconsin. Wisconsin 2011 had no threshold fungicide application. 
under low disease (Paul et al. 2011), and it has been postulated that this is because fungicides manage minor foliar diseases, saprophytic fungi, and delay senescence (Bertelsen et al. 2001; Köehle et al. 2002). Nonetheless, across our trials, lack of a consistent yield increase in the absence of disease was not observed. These results concur with those of Bradley and Ames (2010) who reported variability in yield response of field trials conducted across years. Although Paul et al. (2011) observed increased mean yield response at low levels of disease, it was not always economically beneficial.

TABLE 5. Effect of hybrid on stalk rot disease of corn (0 to 5 scale) assessed at the R6 physiological maturity crop developmental stage, on the stalks of four maize hybrids grown at four sites between 2010 and 2012

\begin{tabular}{|c|c|c|c|}
\hline & $2010^{\mathrm{a}}$ & 2010 & 2011 \\
\hline Hybrid $^{\mathrm{b}}$ & IA & IL & IL \\
\hline 'P35F44' & 1.69 & 2.21 & 1.98 \\
\hline 'P33W84' & 1.53 & 1.88 & 1.72 \\
\hline 'P0461XR' & 1.94 & 2.02 & 1.77 \\
\hline 'P0891XR' & 1.61 & 2.06 & 2.42 \\
\hline LSD & NS & NS & 0.29 \\
\hline$P$ value & 0.6000 & 0.1841 & 0.0003 \\
\hline
\end{tabular}

a Results are presented for stalk rot ratings done in 2010 in Iowa and Illinois and in 2011 only in Illinois. IA, Iowa; IL, Illinois; OH, Ohio; and WI, Wisconsin.

b All hybrids were from DuPont-Pioneer Hi-bred International Inc. 'P35F44', susceptible to GLS and resistant to northern corn leaf blight (NCLB); 'P33W84', resistant to GLS and susceptible to NCLB; 'P0461XR', susceptible to both gray leaf spot (GLS) and NCLB; and 'P0891XR', resistant to both GLS and NCLB.
Our trials were inoculated at two growth stages, with different combinations of $S$. turcica and $C$. zeae-maydis to enhance disease development in the trials. The effect of inoculation on yield was significant in three out of eight site-years (Illinois 2010 and 2011 $P<0.0001$; Iowa $2010 P=0.0092$ ) but more inoculations did not always result in more disease and/or reduced yields. The presence of a pathogen alone does not lead to disease, since the host needs to be susceptible and the prevailing weather conditions must be favorable for the disease to occur (Stack 1999). Since disease in six out of eight site-years was low, the disease triangle conditions leading to increased infection must not have been met. At Wisconsin in 2010 where high yields were observed, the period from July to August had above normal (30-year average) rainfall, corresponding to when maize was at R3 to R4 crop developmental growth stage or beginning grain fill. Genotype by environment interactions could have contributed to the high yields observed. Resistance in hybrid genetics and cultural methods that affect the cropping environment should be considered as part of an IPM system in association with foliar fungicide applications. The goal should be a positive and sustainable yield response under different environments and depending on what the risk factors are on a case by case basis. When continuously used in the absence of need, QoIcontaining fungicides are a cost that may reduce producers' profits and increase risk of fungicide resistance development (Blandino et al. 2012; Bradley and Pedersen 2011; Walker et al. 2009).

Previous studies associate foliar disease development with early onset of senescence, increased risk of stalk rot, reduced grain fill, and consequently lower yields (Stack 1999; Roeth and Elmore 2000). Furthermore, plants with stalk rot are more susceptible to lodging, which can slow down machine harvesting and can result in
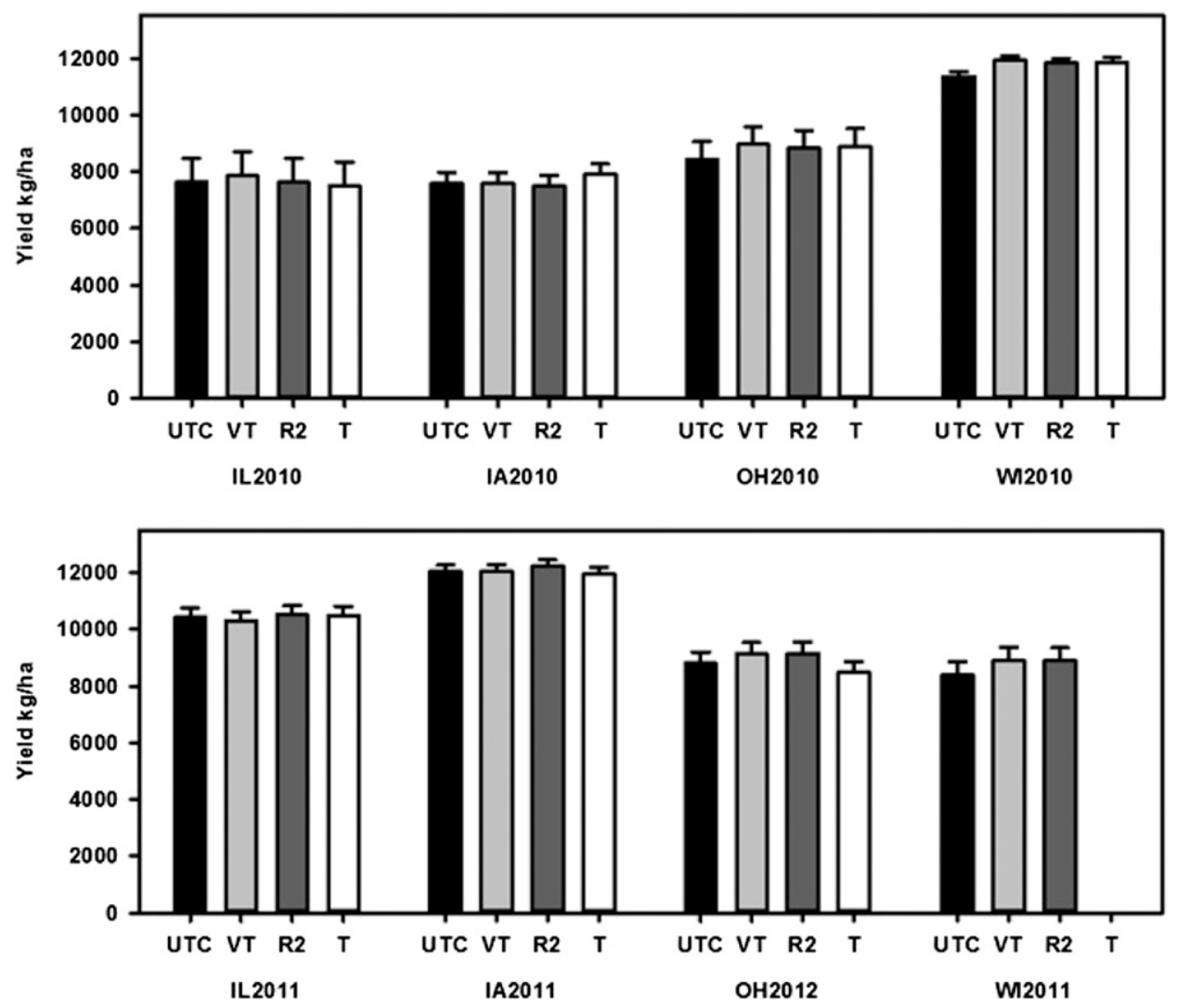

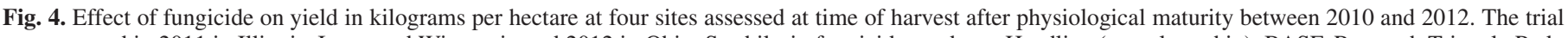

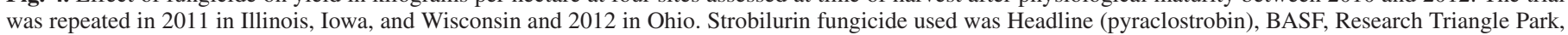

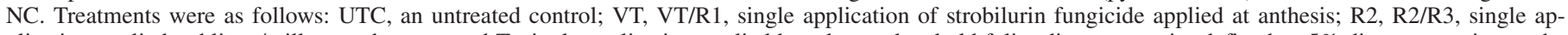

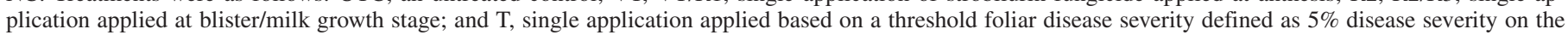

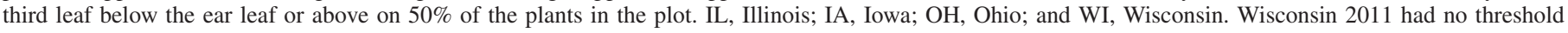
fungicide application. 
dropped ears during harvest (Dodd 1980). In the present study, foliar disease severity ranged from low to moderate, while stalk rot was marginal; the impact of both diseases on yield was generally low.

Our data suggest that fungicide application can be a viable IPM component for hybrid maize production in the U.S. Corn Belt, provided all sides of the disease triangle are met. However, yield advantages as a result of reduced disease or other factors that may be induced by QoI fungicide application, especially when disease is low or absent, were not consistent. More research is needed to define the disease threshold level for fungicide application on hybrids, particularly in light of environmental conditions and hybrid genetics. Successful management of corn foliar diseases should include practices incorporating all four components. These consist of prevention practices such as planting of hybrids with resistance to disease, avoidance practices such as rotation, monitoring practices such as scouting, and suppression practices such as use of pesticides.

\section{ACKNOWLEDGMENTS}

This research was supported by funds from a USDA-NIFA-RAMP grant, project number 2009-51101-05820, entitled, "Sustainable Disease Management on Field Corn in the U.S. Corn Belt." We also thank DuPontPioneer who provided seed for the project. Isolates of either C. zeae-maydis or S. turcica were obtained for Wisconsin USDA permit numbers P526P08-00769 and P526P-08-01569 (C. zeae-maydis) and P526P -10-01323 (S. turcica). We also greatly appreciate all of the efforts of members of each laboratory for their help in coordinating trials and collecting data used in these studies.
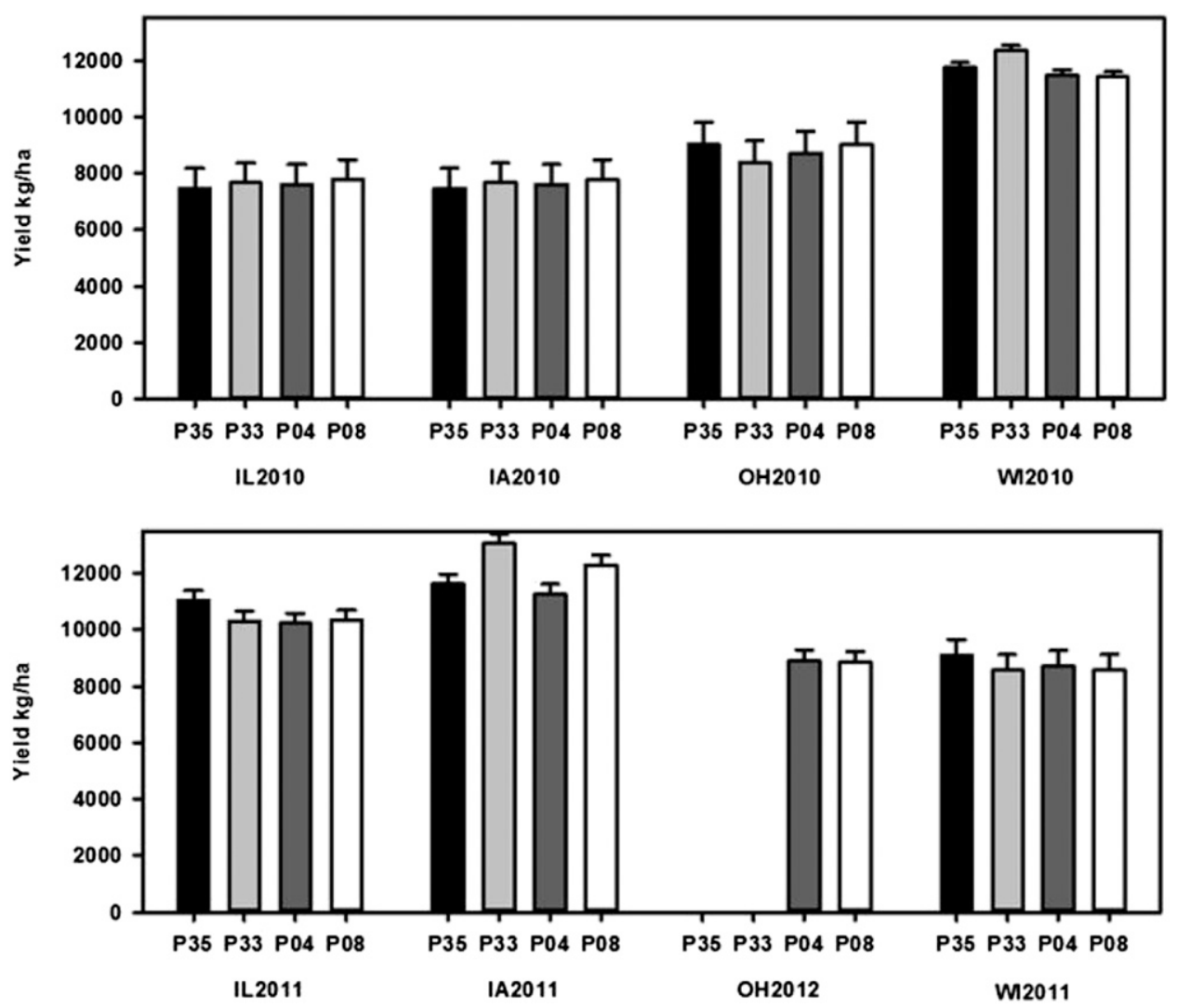

Fig. 5. Effect of hybrid on yield in kilograms per hectare at four sites assessed at time of harvest after physiological maturity of four maize hybrids grown between 2010 and 2012. Trial was repeated in 2011 in Iowa, Illinois, and Wisconsin and 2012 in Ohio. All hybrids were from DuPont-Pioneer Hi-Bred International, Inc. P35, 'P35F44', susceptible to gray leaf spot (GLS) and resistant to northern corn leaf blight (NCLB), P33, 'P33W84', resistant to GLS and susceptible to NCLB, P04, 'P0461XR', susceptible to both GLS and NCLB, and P08, 'P0891XR', resistant to both GLS and NCLB. IA, Iowa; IL, Illinois; OH, Ohio; WI, Wisconsin. Ohio 2012, only two hybrids were evaluated, 'P0461XR' and 'P0891XR'.

TABLE 6. $P$ values summarizing all fixed effect factors related to yield in kilograms per hectare at four sites between 2010 and 2012

\begin{tabular}{|c|c|c|c|c|c|c|c|c|}
\hline \multirow[b]{2}{*}{ Factors $^{\mathrm{b}}$} & \multicolumn{4}{|c|}{$2010^{\mathrm{a}}$} & \multicolumn{4}{|c|}{$2011 / 2012^{a}$} \\
\hline & IA & IL & $\mathrm{OH}$ & WI & IA & IL & $\mathrm{OH}^{\mathrm{c}}$ & $\mathrm{WI}^{\mathrm{d}}$ \\
\hline Hybrid & 0.9912 & 0.1824 & 0.8140 & 0.0011 & 0.0164 & 0.0264 & 0.7044 & 0.7352 \\
\hline Fungicide & 0.4059 & 0.0320 & 0.0199 & $<0.0001$ & 0.5536 & 0.8606 & 0.1175 & 0.0012 \\
\hline Inoculation & 0.4598 & $<0.0001$ & 0.2398 & 0.1883 & 0.0092 & $<0.0001$ & 0.3263 & 0.9959 \\
\hline $\mathrm{H} \times \mathrm{I}$ & 0.5630 & 0.1047 & 0.3814 & 0.7424 & 0.7175 & 0.0089 & 0.4853 & 0.1753 \\
\hline $\mathrm{F} \times \mathrm{I}$ & 0.2920 & 0.8847 & 0.2046 & 0.7253 & 0.3150 & 0.9807 & 0.3057 & 0.5864 \\
\hline
\end{tabular}

a The trial was repeated in 2011 in Iowa, Illinois, and Wisconsin and 2012 in Ohio. IA, Iowa; IL, Illinois; OH, Ohio; and WI, Wisconsin.

${ }^{\mathrm{b}}$ Main effects and their interactions: H, hybrid, F, fungicide; and I, inoculation.

c Ohio 2012, only two hybrids were evaluated 'P0461XR' and 'P0891XR'.

${ }^{\mathrm{d}}$ Wisconsin 2011, no threshold fungicide application. 


\section{LITERATURE CITED}

Abendroth, L. J., Elmore, R. W., Boyer, M. J., and Marlay, S. K. 2011. Corn growth and development. PM R: 1009. Iowa State University Extension, Ames, IA.

Balint Kurti, P. J., and Johal, G. 2009. Maize disease resistance. Pages 229-250 in: Handbook of Maize. Springer Science and Business Media.

Bartlett, D. W., Clough, J. M., Godwin, J. R., Hall, A. A., Hamer, M., and Parr-Dobrzanski, B. 2002. The strobilurin fungicides. Pest Manag. Sci. 58: 649-662.

Battaglin, W. A., Sandstrom, M. W., Kuivila, K. M., Kopin, D. W., and Meyers, M.T. 2011. Occurrence of azoxystrobin, propiconazole, and selected other fungicides in US streams, 2005-2006. Water Air Soil Pollut. 218:307-322.

Bertelsen, J. R., de Neergaard, E., and Smedegaard-Petersen, V. 2001. Fungicidal effects of azoxystrobin and epoxiconazole on phyllosphere fungi, senescence and yield of winter wheat. Plant Pathol. 50:190-205.

Bhatia, A., and Munkvold, G. P. 2002. Relationships of environmental and cultural factors with severity of gray leaf spot on maize. Plant Dis. 86:1127-1133.

Blandino, M., Galeazzi, M., Savoia, W., and Reyneri, A. 2012. Timing of azoxystrobin+propiconazole application on maize to control northern corn leaf blight and maximize grain yield. Field Crops Res. 139:20-29.

Boosalis, M. G., Doupnik, B. L., and Watkins, J. E. 1986. Pages 389-408 in: No-Tillage and Surface-Tillage Agriculture. John Wiley and Sons, Inc., New York.

Bradley, C. A. 2012. Factors considered when making corn foliar fungicide application decisions in Illinois. J Exten. 50(3):3RIB7. http://www.joe. org/joe/2012june/rb7.php

Bradley, C. A., and Ames, K. A. 2010. Effect of foliar fungicides on corn with simulated hail damage. Plant Dis. 94:83-86.

Bradley, C. A., and Pedersen, D. K. 2011. Baseline sensitivity of Cercospora zeae-maydis to quinone outside inhibitor fungicides. Plant Dis. 95:189-194.

Brent, K. J., and Hollomon, D W. 2007. Fungicide resistance: The assessment of risk. FRAC Monograph No. 2:1-28.

Costa, R. V., Luciano V. T., Dagma Dionísia, da S., Fernandes, W. M., and Eustáquio, F. L. 2012. Viabilidade técnica e econômica da aplicação de estrobilurinas em milho. Trop. Plant Pathol. 37:246-254.

Coulter, J. A. 2010. Response of corn hybrids with differing maturity to foliar fungicide in Minnesota, 2009. Plant Dis. Manage. Rep. 3:FC027.

Dodd, J. L. 1980. The role of plant stresses in development of corn stalk rots. Plant Dis. 64:533-537.

Elmore, R. W. 2013. Advances, vulnerabilities, and opportunities for corn: A perspective from Iowa. Pages 3-15 in: Climate Vulnerability: Understanding and Addressing Threats to Essential Resources. D. Niyogi, ed. Elsevier Inc., Academic Press.

Environment Canada. 2011, Calculation of the 1971 to 2000 Climate Normals for Canada. Government of Canada. http://climate.weatheroffice.gc. ca/prods_servs/normals_documentation_e.html

Hewitt, H. G. 1998. Fungicides in Crop Protection. CABI Publishing, CAB International, Oxon, UK.

Hines, R. 2007. Stalk rot impacts of foliar fungicides on corn. Paper presented at the 62nd Annu. Corn Sorghum Seed Res. Conf. Chicago. American Seed Trade Association, Alexandria, VA.

Johnson, K. B. 1987. Defoliation, disease, and growth: A reply. Phytopathology 77:1495-1497.

Köehle, H., Grossmann, K., Jabs, T., Gerhard, M., Kaiser, W., Glaab, J., Conrath, U., Seehaus, K., and Herms, S. 2002. Physiological effects of the strobilurin fungicide F 500 on plants. Pages 61-74 in: Modern Fungicides and Antifungal Compounds III. H. W. Dehne, eds. Mann GmbH \& Co. KG, Bonn, Germany.

Littell, R. C., Milliken, G. A., Stroup, W. W., Wolfinger, R. D., and Schabenberger, O. 2006. SAS for Mixed Models, 2nd Ed. SAS Institute, Cary, NC.

Mueller, D., and Sisson, A. 2013. Corn Field Guide. CSI 0001. Iowa State University Extension, Ames, IA.
Munkvold, G. P. 1997. Controlling gray leaf spot in field corn. IC-478 (12). Iowa State University Extension. Ames, IA. http://www.ipm.iastate. edu/ipm/icm/1997/6-9-1997/contgspot.html

Munkvold, G. P., Doerge, T., and Bradley, C. 2008. IPM is still alive for corn leaf disease: Look before you spray. In: Proc. 62nd Annu. Corn Sorghum Res. Conf. Chicago, American Seed Trade Association, Alexandria, VA.

Munkvold, G. P., and Gorman, D. 2006. Foliar fungicide use in corn. Crop Insights 16:1-6.

Munkvold, G. P., Martinson, C. A., Shriver, J. M., and Dixon, P. M. 2001. Probabilities for profitable fungicide use against gray leaf spot in hybrid maize. Phytopathology 91:477-484.

Nafziger, E. 2009. Corn. Pages 13-26 in: Illinois Agronomy Handbook, 24th ed. University of Illinois Extension, Urbana-Champagne, IL.

Nelson, K. A., and Meinhardt, C. G. 2011. Foliar boron and pyraclostrobin effects on corn. Agron. J. 103:1352-1358.

Paul, P. A., Madden, L. V., Bradley, C. A., Robertson, A., Munkvold, G., Shaner, G., Wise, K., Malvick, D., Allen, T. W., Grybauskas, A., Vincelli, P., and Esker, P. 2011. Meta-analysis of yield response of hybrid field corn to foliar fungicides in the U.S. Corn Belt. Phytopathology 101:1122-1132.

Paul, P. A., and Munkvold, G. P. 2005. Influence of temperature and relative humidity on sporulation of Cercospora zeae-maydis and expansion of gray leaf spot lesions on maize leaves. Plant Dis. 89:624-630.

Roeth, F. W., and Elmore, R. W. 2000. G1398 Corn Grain Yield and Kernel Weight Stability after Black Layer. Paper 73 in: Historical Materials from University of Nebraska-Lincoln Extension. http://digitalcommons.unl.edu/extensionhist/73? utm_source=digitalcommons.unl.edu $\% 2$ Fextensionhist $\% 2$ F73\&utm_medium = PDF\&utm_campaign=PDFCoverPages

Ruske, R. E., Gooding, M. J., and Jones, S. A. 2003. The effects of triazole and strobilurin fungicide programmes on nitrogen uptake, partitioning, remobilization and grain $\mathrm{N}$ accumulation in winter wheat cultivars. J. Agric. Sci. 140:395-407.

Shah, D. A., and Dillard, H. R. 2010. Managing foliar diseases of processing sweet corn in New York with strobilurin fungicides. Plant Dis. 94: 213-220.

Stack, J. 1999. G99-1385 Common Stalk Rot Diseases of Corn. Paper 1260 in: Historical Materials from University of Nebraska-Lincoln Extension. http:// digitalcommons.unl.edu/extensionhist/1260

Thomison, P., Lipps, P., Hammond, R., Mullen, R., and Eisley, B. 2005. Corn Production Agronomy Guide, 14th ed. Bulletin 472. The Ohio State University Extension, Columbus, $\mathrm{OH}$.

Venâncio, W. S., Rodrigues, M. A. T., Begliomini, E., and Souza, N. 2003. Physiological effects of strobilurin fungicides on plants. Publ. UEPG 9: 59-68.

Vincelli, P. 2002. $Q_{0} I$ (strobilurin) fungicides: Benefits and risks. The Plant Health Instructor.

Walker, A. S., Auclair, C., Gredt, M., and Leroux, P. 2009. First occurrence of resistance to strobilurin fungicides in Microdochium nivale and Microdochium majus from French naturally infected wheat grains. Pest Manag. Sci. 65:906-915.

Wallhead, M. 2012. Foliar fungicide effects on gray leaf spot and yield of hybrid maize as influenced by application timing, hybrid characteristics and production practices. Master's thesis, Ohio State University.

Ward, J. M. J., Laing, M. D., and Rijkenberg, F. H. J. 1997. Frequency and timing of fungicide applications for the control of gray leaf spot in maize. Plant Dis. 81:41-48.

Wegulo, S. N., Martinson, C. A., Rivera-C., J. M., and Nutter, F. W., Jr. 1997. Model for economic analysis of fungicide usage in hybrid corn seed production. Plant Dis. 81:415-422.

White, D. G. 1999. Compendium of Corn Diseases. 3rd ed. American Phytopathological Society, St. Paul, MN.

Wise, K., and Mueller, D. 2011. Are fungicides no longer just for fungi? An analysis of foliar fungicide usein corn. APSnet Features.

Wu, Y., and Von Tiedemann, A. 2002. Impact of fungicides on active oxygen species and antioxidant enzymes in spring barley (Hordeum vulgare L.) exposed to ozone. Environ. Pollut. 116:37-47. 